\title{
Analyzing Impacts of Renewable Energy Directive (RED) Policy on Crude Palm Oil (CPO) Export and Forecasting CPO Export from Indonesia to European Union (EU) for 2019-2020 Using ARIMA Intervention Analysis
}

\author{
Anni Syahdia Nasution \\ Statistics \\ Politeknik Statistika STIS \\ DKI Jakarta, Indonesia \\ 14.7996@stis.ac.id
}

\author{
Ika Yuni Wulansari \\ Statistics \\ Politeknik Statistika STIS \\ DKI Jakarta, Indonesia \\ 0000-0002-8649-1626
}

\begin{abstract}
The implementation of Renewable Energy Directive (RED) policy on April 2009 by European Union (EU) received several responses from many countries, due to create nontariff barrier in international trade. RED $(2009 / 28 / E C)$ established an overall policy for the production and promotion of energy from renewable sources in the EU. It requires the EU to fulfil at least $20 \%$ of its total energy needs with renewables by 2020. One of the countries affected by RED policy is Indonesia. The EU includes Crude Palm Oil (CPO) as a nonenvironmentally friendly product on its RED. After this policy was set, Indonesia's CPO exports to the EU fell from 275.162,425 metrict tons (MT) to 236.653,661 MT and the next month just 896,876 MT. This research purposes to analyze RED policy and its duration impact on Indonesia's CPO exports to the EU. This research uses ARIMA Intervention to analyze monthly data of Indonesia's CPO exports from January 2002 to December 2018 (before and after policy implementation) and forecast the monthly increment of CPO export from Indonesia to EU for 2019 until 2020. It is obtained that RED policy gave an impact on declining of Indonesia's CPO exports to the EU only two months after the policy was set. RED policy has a temporary effect. Forecasting results show the monthly increment volume of Indonesia's CPO exports to the EU from January 2019 to 2020 will experience an upward trend. The lowest increment of export volume is in Januari $2020(298,527$ MT) and the highest is in August 2020 (330,063 MT).
\end{abstract}

Keywords-Renewable Energy Directive (RED), CPO, European Union, Indonesia, ARIMA Intervention

\section{INTRODUCTION}

In 2018, the plantation sub-sector contributed 13,26 percent to the formation of GDP in the agricultural sector (publication of the Central Bureau of Statistics, 2018). In addition, the plantation sub-sector is also a provider of raw materials in the industrial sector, absorbing labor, and generating foreign exchange. Plantation products that are exported and become Indonesia's main commodity are oil palm. (Maygirtasari, Yulianto, \& Mawardi, 2015). Based on the results of the publication of statistics on Indonesian plantations in 2016 (Ministry of Industry, 2017), Indonesian oil palm plantations play an important role in absorbing domestic workforce, as many as 5,6 million people with details of 2,2 million including details of small-scale farmers. If observed as a whole, there are an estimated 16 to 20 million people who rely on their livelihoods from the upstream and downstream palm oil businesses which are spread evenly throughout Indonesia. Based on published data from the Central Bureau of Statistics (BPS) in 2018, Indonesia's main foreign exchange-producing machinery still comes from palm oil, which is around US \$ 22,97 billion, followed by coal around US \$21,07 billion, and oil and gas in around US \$ 13,1 billion.

One of the potential commodities in the plantation subsector is oil palm (CPO). UN Comtrade (2017) notes that Indonesia is the largest CPO producer in the world today. based on published data from the BPS, Indonesia's three main CPO exports destination country are India, the European Union (EU), and the United States. But, lately the European Union has begun to make various regulations regarding environmental standards in various industries, one of which is the policy governing biofuel derived from palm oil, the Renewable Energy Directive (RED) on April 23, 2009.

RED is an EU policy that aims to control the European Union in reducing greenhouse gas emissions by at least 20 percent and increasing the use of renewable energy by 20 percent in energy consumption by 2020. The European Union is also committed to increasing emissions reductions by up to 30 percent by 2020 when global climate change agreement reached. In addition, RED also highlights the issue of renewable energy in the transportation sector with the use of biofuels, where RED sets a binding target of 20 percent.

Several studies have been conducted on the effect of RED policy on CPO exports. Khairunnisa, G.R \& Novianti, T. (2017) conducted research on the Analysis of the Competitiveness of Palm Oil and the Impact of the EU Renewable Energy Directive on Indonesian Exports in the EU Market using Revealed Compatitive Advantage (RCA) analysis, Export Products, Dynamics Export Products (EPD), and gravity models, with research sites from seven European 
Union member states. The results of this study are that Indonesian palm oil has a superior competitive position in the European Union market compared to competing countries such as Malaysia, Colombia, Ecuador and Thailand. However, Indonesia's palm oil experienced a decline in export performance to seven European Union member states in 2007-2008 and in 2011-2012. With gravity analysis, it was found that one of the factors that significantly affects the value of Indonesia's palm oil exports is the Renewable Energy Directive policy.

Kartika, I.T. (2016), analyzed interaction of the Renewable Energy Policy (RED) and the Indonesian Sustainable Palm Oil (ISPO) Policy on Indonesia's Palm Oil Exports to the European Union resulted in a RED policy caused trade barriers. In addition, the interaction of the two policies is a policy that interacts because remembering that ISPO was formed in response to RED so as to prove that Indonesian palm oil is in accordance with the principles of environmental protection.

Kurniawan, Aprilian Indra (2018) analyzed European Union protectionism policy and its impact on Indonesia's exports of Crude Palm Oil (CPO) to Europe. It uses primary data collection methods by conducting interviews with related and secondary sources through literature studies or data on policies issued by the European Union in regulating the entry of CPO products in the EU. This study resulted the establishment of policies, namely, the Renewable Energy Directive (RED), labeling Palm Oil Free (POF), and the Resolution of Palm Oil and Rainforest Deforestation by the European Parliament made the barriers. It is difficult for Indonesian CPOs to enter Europe and products made from palm oil will be difficult to compete with other vegetable oil based products, namely rapeseed oil and sunflower.

\section{Methodology}

In this study the data used is secondary data on the volume of Indonesian CPO exports to the European Union from January 2002 to December 2018 by referring to the CPO commodity classification code following the Harmonize System (HS), which is 151110000 in the form of monthly time series data obtained from data from the BPS. Based on the period used, total observations are 204 data series with units of thousands of metric tons (TM).

The analytical method used in this study which aims to answer the research objectives is to use a descriptive analysis method (presenting data in graphical form to provide an overview of the development of Indonesia's CPO export volume from January 2002 to December 2018 and in the form of tables to provide a summary of the results of calculations) and inferencing analysis (using the ARIMA intervention model, which aims to analyze the impact of an intervention that affects time series data so that with the ARIMA model the intervention can be analyzed when the intervention starts to impact, how much impact the intervention has on the data, and whether the impact of the intervention will temporary or permanent impact in the future, and how the results of forecasting the next 24 months)
The AR, MA, ARMA and ARIMA models use the assumption that the time series data generated is already stationary. The general form of the ARIMA model can be stated in the following equation (Box, G.E.P. and Tiao, G.C. ,1975):

$$
\emptyset_{\mathrm{p}}(\mathrm{B})(1-\mathrm{B})^{\mathrm{d}} \mathrm{Z}_{\mathrm{t}}=\theta(\mathrm{B}) e_{\mathrm{t}}
$$

Note :

$$
\begin{aligned}
& \emptyset_{p}(B) \quad: \operatorname{AR}(\mathrm{p}) \\
& (1-B)^{d} X_{t}: \text { period difference }(d) \\
& \theta(B) \quad: \operatorname{Ma}(\mathrm{q})
\end{aligned}
$$

If a data is influenced by an event that occurs unexpectedly or a policy issued by an agency is a form of intervention that will cause data patterns to change at one time. The intervention function for one intervention variable is defined as follows:

$$
f\left(I_{t}\right)=y_{t}\left(s_{s}, r, b\right)=\frac{\omega_{s}(B)}{a_{r}(B)}
$$

General formula for the ARIMA step function intervention:

$$
Z_{\mathrm{t}}=f\left(\beta_{s} I_{\mathrm{t}}\right)=\frac{\omega_{x}(B)}{\sigma_{r}(B)} B^{b} S_{\mathrm{t}}^{(T)}+N_{\mathrm{t}}
$$

The ARIMA equation intervenes if the results of the transformation $(\lambda)$ are:

$$
Z_{t}(\lambda)=f\left(\beta, I_{t}\right)=\frac{\omega_{s}(B)}{\sigma_{r}(B)} B^{b} S_{t}^{(T)}+N_{t}
$$

Note :

$\mathrm{b}$ :the number of periods before the $I_{\mathrm{t}}$ input starts effecting $Z_{t}$

$\mathrm{s}:$ the number of $I_{t}$ values that effect $Z_{t}$

$\mathrm{r}$ :number of periods before $I_{t}$ input that corresponds to $Z_{\mathrm{t}}$

$\omega_{g}:$ the amount of decrease in the level (mean)

$\omega_{g}(B): \omega_{0}-\omega_{1}(B)-\ldots-\omega_{g} B^{g}$

$\delta_{y}$ :form of delay as a result of the effect of the intervention

$\delta_{y}(B): 1-\delta_{1}(B)-\ldots-\delta_{y} B^{r}$

\section{RESULT AND DISCUSSION}

Data on Indonesia's CPO export volume to the European Union from January 2002 to December 2018 will be analyzed using the step function intervention method. 


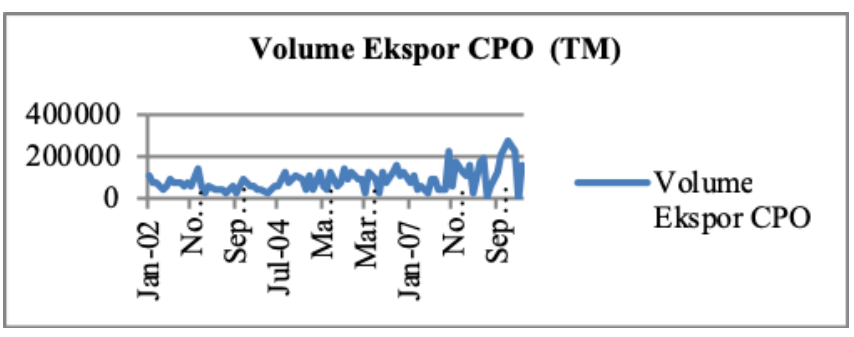

Source: Statistics Indonesia (processed)

Fig. 1. Plot of Indonesian CPO export volume data after the intervention

Figure 1 shows the pattern of data before the intervention. The data plot seen before the intervention has an upward trend, means that Indonesia's CPO export volume has a good performance in its exports. However, in terms of CPO export intervention to the European Union (Figure 2), Indonesia's $\mathrm{CPO}$ exports to the European Union on average have decreased. This decrease can be seen that the biggest decrease occurred in December 2009 to January 2010. In addition, this decline was also caused by a drop in exports of CPO-derived products by minus 17,87 percent. GAPKI explained that this decline occurred due to the decrease in exports of RBD Stearin and Olein / Refined Bleaching Deodorize stearin and olein by minus 27,55 percent, from 160,082 tons to 115,972 tons and from 379,138 tons to 285,782 tons

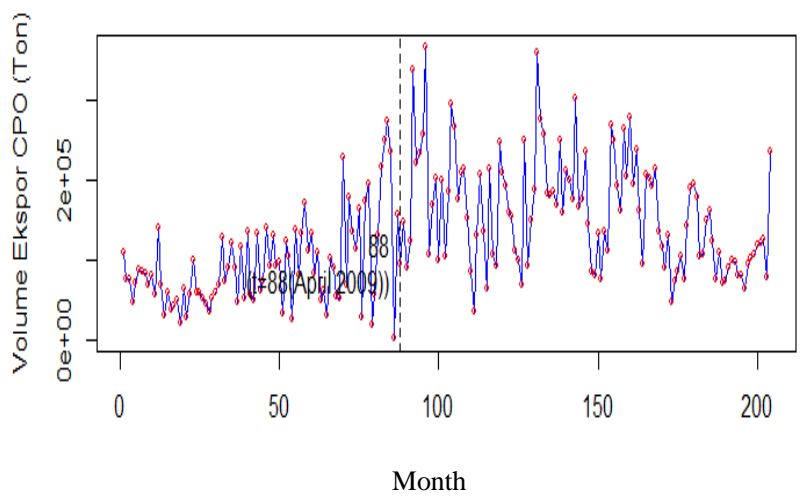

Source: Statistics Indonesia (processed)

Fig. 2. Plot of Indonesian CPO export volume data after the intervention

From Figure 16, it can be seen that the volume of Indonesia's CPO exports to the European Union since January 2002 experienced an upward trend, but in May 2009 Indonesia's CPO exports experienced a decline which then in the following months on average returned to an upward trend, this was due to regulations the Ministry of Trade stipulated in the Minister of Trade Regulation No. 15/MDAG/PER/4/2009 dated April 25, 2009 and takes effect on May 1, 2009.

\section{A. ARIMA and ARIMA Intervention}

From the results of calculating the test statistics for the Ljung-Box test and the Kolmogorov-Smirnov test in Table I below, it appears that the test resulted a failure to reject $\mathrm{H}_{0}$ at $\alpha=0.05$ which means that the residual value for the ARIMA model $(0,1,1)$ meets white noise assumptions (Ljung-Box and Chi Square Test) and normality. By fulfilling this assumption, the ARIMA model $(0,1,1)$ is said to be adequate and can be used for forecasting.

In the previous analysis, looking for ARIMA models before the intervention was done forecasting where the forecasting results are used to find the residual value of the intervention response. From the results of the calculation it can be concluded that at the time of the intervention namely $T=88$ (April 2009) there was a decrease in the volume of Indonesian CPO exports to the EU after the intervention time.

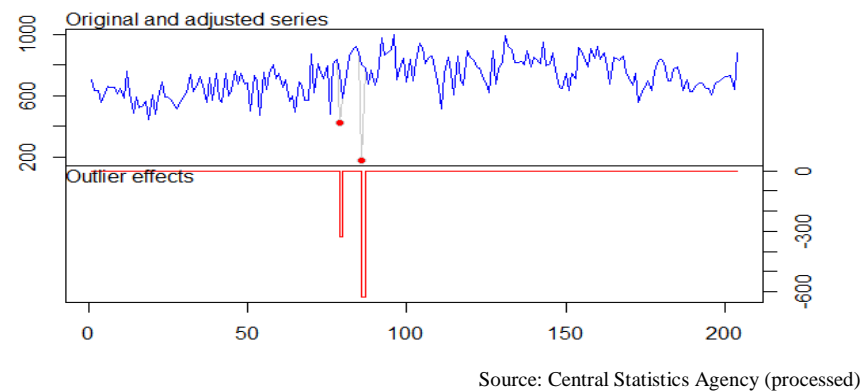

Fig. 3. Plot of Residual Patterns

From the picture it can be seen that interventions occured gradually and only have a temporary impact so that the pattern of the impact of the intervention follows a gradual temporary pattern. This means that the RED policy issued by the EU parliament is only temporary in reducing the volume of Indonesia's CPO exports to the country.

TABLE I. PARAMETER ESTIMATION RESULTS, PARAMETER SIGNIFICANCE TESTS AND DIAGNOSTIC TESTS

\begin{tabular}{crrrrr}
\hline Estimate & P-Value & Lag & $\begin{array}{c}\text { Ljung- } \\
\text { Box } \\
\text { Statistic }\end{array}$ & $\chi^{z}$ & $\begin{array}{c}\text { Kolmogoro } \\
\text { v-Smirnov }\end{array}$ \\
\hline$\Theta=0,67009$ & $<0,0001$ & 6 & 9,42 & 12,592 & \\
& 12 & 17,17 & 21,026 & 0,126 \\
& 18 & 22,66 & 28,869 & \\
& 24 & 32,62 & 36,415 & \\
\hline & & \multicolumn{4}{c}{ Source: Central Statistics Agency (processed) }
\end{tabular}

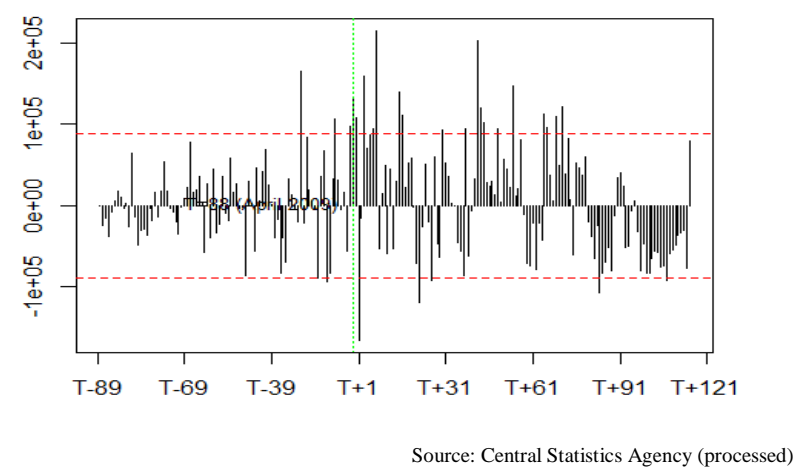

Fig. 4. Plot of Intervention Patterns

Information :

- The green line is the time for the RED policy to take effect

- The red line is the residual interval of $\pm 2 \sigma$ 
The Figure 4 shows that in the second lag $(T+2)$ is the first time the residual plot of the forecast results exceeds the $2 \sigma$ limit so that the order value $b$ can be estimated to be 2 (b $=2$ ). This means that the RED policy issued by the European Union parliament be felt by Indonesia after the impact of the policy in 2 months. This is possible because the European Union countries are still undergoing adjustments to policies that are implemented to meet the needs of the country.

TABLE II. PARAMETER ESTIMATION RESULTS, PARAMETER SIGNIFICANCE TESTS AND DIAGNOSTIC TESTS ARIMA INTERVENTION

\begin{tabular}{|c|c|c|c|c|c|}
\hline Estimate & P-Value & $\begin{array}{c}\mathrm{La} \\
\mathrm{g}\end{array}$ & $\begin{array}{l}\text { Ljung- } \\
\text { Box } \\
\text { Statistic }\end{array}$ & $x^{2}$ & $\begin{array}{c}\text { Kolmogor } \\
\text { ov- } \\
\text { Smirnov }\end{array}$ \\
\hline $6=-0,2845$ & $<0,0001$ & 6 & 9,40 & 12,592 & \multirow{4}{*}{0,06868} \\
\hline$\widehat{\omega}_{0}=-12,80921$ & $<0,0001$ & 12 & 17,15 & 21,026 & \\
\hline$\widehat{\omega}_{1}=-15,48712$ & $<0,0001$ & 18 & 22,64 & 28,869 & \\
\hline & & 24 & 32,59 & 36,415 & \\
\hline
\end{tabular}

So that the results can be obtained as follows:

$$
Z_{t}(a)=\frac{\tilde{\omega}_{0}-\tilde{\omega}_{1} B}{1-\delta(B)} I_{t}+N_{t}
$$

And the response to an intervention is:

$$
Z_{t}=\frac{-1280921-(-15,48712) B^{2}}{1-(-0,28450) B^{2}} S_{8 g}
$$

With the ARIMA Model:

$$
N_{t}(\lambda)=\frac{(1-0,67009 B) \varepsilon_{t}}{(1-B)}
$$

So the step equation function of the intervention model is :

$$
Z_{t}(\lambda)=\frac{-12,80921-(-15,49712) B^{2}}{1-(-0,28450) B^{2}} S_{98}+\frac{(1-0,67009 B) e_{t}}{(1-B)^{2}}
$$

Meaning: in intervention $\mathrm{b}=2$ means that RED intervention occurred in 88 data and had the first impact, that is 2 months after the policy came into effect. Meanwhile, $I$ has a negative value, means that the initial impact after the implementation of the RED policy cause a decrease in the volume of Indonesia's CPO exports to the European Union.

\section{B. Forecasting using ARIMA Intervention}

Forecasting of increment monthly data on Indonesia's CPO export volume to the EU in January 2019 to December 2020,that is obtained as follows:

TABLE III. FORECASTING OF INCREMENT ON INDONESIA'S CPO EXPORT VOLUME TO THE EU

\begin{tabular}{|c|c|c|c|}
\hline Time & $\begin{array}{c}\text { Forecast of } \\
\text { Increment (MT) }\end{array}$ & Time & $\begin{array}{c}\text { Forecast of } \\
\text { Increment (MT) }\end{array}$ \\
\hline Jan-19 & 325,8296 & Jan-20 & 298,5275 \\
\hline Feb-19 & 329,3045 & Feb-20 & 298,7242 \\
\hline Mar-19 & 328,0480 & Mar-20 & 299,9721 \\
\hline
\end{tabular}

\begin{tabular}{|c|c|c|c|}
\hline Time & $\begin{array}{c}\text { Forecast of } \\
\text { Increment (MT) }\end{array}$ & Time & $\begin{array}{c}\text { Forecast of } \\
\text { Increment (MT) }\end{array}$ \\
\hline Apr-19 & 326,5831 & Apr-20 & 302,2147 \\
\hline Mei-19 & 323,3852 & Mei-20 & 306,4319 \\
\hline Jun-19 & 322,8746 & Jun-20 & 310,5065 \\
\hline Jul-19 & 323,7919 & Jul-20 & 314,8200 \\
\hline Agu-19 & 319,7012 & Agu-20 & 330,0635 \\
\hline Sep-19 & 317,8998 & Sep-20 & 309,3381 \\
\hline Okt-19 & 316,0035 & Okt-20 & 328,8774 \\
\hline Nov-19 & 310,8073 & Nov-20 & 327,6914 \\
\hline Des-19 & 306,3583 & Des-20 & 326,5053 \\
\hline Source : forecasting results of the ARIMA Intervention &
\end{tabular}

Based on the results of research and discussions that have been carried out, then conclusions can be taken. The results of forecasting the volume of Indonesian CPO exports to the EU with the step function intervention model over the next 20 periods can be concluded that the forecasting results with the step function intervention model show that the forecast results are within the confident interval 95\%. It is seen that the smallest forecast of increments CPO export volume is in January 2020 amounted to 298,5275 MT, the largest of it is in August 2020 amounted to 330,0635 MT.

This result can be used as a post-intervention evaluation material due to the enactment of the RED II policy and preparation for continued RED policy after 2020. Through intervention analysis in this research, we can conclude that Indonesia's CPO export volume within eight months can adapt the RED policy effect issued by the EU. Furthermore, CPO exports Indonesia to EU still increase based on monthly forecasting results from 2019 to 2020.

\section{Suggestion}

1) Judging from the results of the study, Indonesia's CPO export volume began to stabilize, eight months after the RED policy had an impact on Indonesia's CPO export volume to the European Union, which indicated that Indonesia was still quite slow in adjusting, so that in the event of a shock it could make adjustments more quickly in the future.

2) It is necessary to improve the quality of CPO so that the volume of Indonesia's CPO exports to the European Union can increase in accordance with the forecasting results so that Indonesia's CPO exports can survive if there is a policy of implementing a continued RED in late 2020 .

3) Bring to the WTO forum, to negotiate and find a middle ground for discriminative treatment of palm oil and its derivative products.

4) Lower price (price reference)

5) Implement zero export tariffs to increase the enthusiasm of exporters

6) Collaboration with foreign ministry to resolve the issue with the help of a diplomatic approach 


\section{REFERENCES}

[1] Box, G. E. P., \& Jenkins, G. M., 1970. Time Series Analysis Forecasting and Control. San Fransisco: Holden-Day.

[2] Box, G.E.P. and Tiao, G.C. (1975). Intervention Analysis with Application to Economic and Environmental Problems. Journal of American Statistical Association, 70: 70-79

[3] Box, G. E. P., Jenkins, G. M., \& Reinsel, G.C., 1994. Time Series Analysis Forecasting and Control 3rd Edition. New Jersey: Prentice Hall.

[4] Central Bureau of Statistics (BPS), https://www.bps.go.id/

[5] Gujarati, D.N., \& Porter, D.C. 2009. Basic Econometrics (5th ed). McGraw-Hill Irwin, New York

[6] Kartika, I.T. (2016). Interaksi Kebijakan Renewable Energy Directive (RED) dan Kebijakan Indonesia Sustainable Palm Oil Terhadap Ekspor Kelapa Sawit Indonesia ke Uni Eropa. [Thesis]. Makassar : Universitas Hasanuddin.

[7] EU Policies, accessed on Januari $10^{\text {th }}, 2019$.

http://eeas.europa.eu/delegations/indonesia/key_eu_policies/energy/in dex_id.htm

[8] https://www.thejakartapost.com/news/2019/08/05/govt-lacks-strongmeasures-against-palm-oil-barriers-says-association.html

[9] https://www.google.com/amp/s/www.thejakartapost.com/amp/news/2 019/03/19/indonesia-prepares-to-take-dispute-with-eu-on-palm-oil-towto.html
[10] https://www.google.com/amp/s/www.thejakartapost.com/amp/news/2 019/03/19/indonesia-prepares-to-take-dispute-with-eu-on-palm-oil-towto.html

[11] https://www.google.com/amp/s/www.thejakartapost.com/amp/news/2 018/08/27/cpo-price-weakens-zero-export-tariff-maintained-inseptember.html

[12] Hull, J. W., Clarkin, J.F. and Alexopoulos, G.S. (1993). Time Series Analysis of Intervention Effects Fluoxetine Therapy as a Case Illustration. Journal of Nervous \& Mental Disease, 181(1): 48-53.

[13] Khairunnisa, G.R \& Novianti, T. (2017). Analisis Daya Saing Minyak Sawit dan Dampak Renewable Energy Directive (RED) Uni Eropa Terhadap Ekspor Indonesia di Pasar Uni Eropa. [Jurnal Agribisnis Indonesia] Vol 5 No 2, Desember 2017. Halaman 125-136.

[14] Kurniawan, Aprilian Indra. (2018). Kebijakan Proteksionisme Uni Eropa dan Dampaknya Terhadap Ekspor Crude Palm Oil (CPO) Indonesia ke Eropa. [Thesis]. Bandung: Universitas Pasundan.

[15] Renewable Energy Directive 2009/28/EC page 36

[16] Suhartono, Nuvitasari. (2007). Evaluasi Dampak Krisis Moneter, Bom Bali I dan II terhadap Jumlah Kunjungan Wisatawan ke Bali dengan Model Intervensi Multi Input. Jurnal Ilmiah MatStat.

[17] UN Comtrade

[18] Wei, W.W.S. 2006. Time Series Analysis: Univariate and Multivariate 2nd Edition. New Jersey: Pearson Education

[19] Wei, W.W.S. 1990. Time Series Analysis. Addison Wisley Publishing Company. Canada. 